\title{
An ostracod fauna from the upper Langport Member (Penarth Group: Rhaetian, Upper Triassic) near Watchet, west Somerset (UK), including two new species of Eucytherura and Cytherelloidea praepulchella n. nom.
}

\author{
ANDREW SWIFT \\ Palaeobiology Group, Department of Geology, University of Leicester, Leicester LE1 7RH, UK \\ (e-mail: as48@le.ac.uk)
}

\begin{abstract}
An abundant ostracod fauna consisting of just five species is described from the upper part of the Langport Member of the Lilstock Formation of the Penarth Group (Rhaetian, Late Triassic) near Watchet, west Somerset. The fauna is dominated by Ogmoconchella bristolensis (Anderson) and Cytherella plattensis Anderson. The only other ostracods present are two new species of Eucytherura, and a form previously identified as Cytherelloidea pulchella Apostolescu or Cytherelloidea cf. pulchella, which is here revised and renamed Cytherelloidea praepulchella. J. Micropalaeontol. 22(2): 127-136, November 2003.
\end{abstract}

\section{INTRODUCTION}

Ostracods are fairly common at several levels within the Penarth Group (Upper Triassic) of Britain, especially in the higher beds, but species diversity is low. No new species have been described from onshore exposures since the pioneering work of Anderson (1964), which was reviewed as part of a summary of the ostracod fauna of the Penarth Group by Boomer et al. (1999). A $250 \mathrm{~g}$ sample taken from the basal bed of the shaly upper part of the Langport Member ('Watchet Beds' of old nomenclature), $92 \mathrm{~cm}$ above its base, in a cliff exposure at Warren Bay, west of Watchet, Somerset, yielded an exceptionally abundant ostracod fauna, including two new species referable to the genus Eucytherura. These new species are described here, together with a revision of the form previously attributed to Cytherelloidea pulchella Apostolescu or $C$. cf. pulchella, and here renamed Cytherelloidea praepulchella. Brief taxonomic remarks are presented on the only other two species of ostracod present; Cytherella plattensis Anderson and Ogmoconchella bristolensis (Anderson).

\section{STRATIGRAPHY}

The Watchet area (Fig. 1a, b), despite extensive faulting and the ephemeral nature of cliff sections due to landslips, is important in the history and evolution of Late Triassic and Early Jurassic stratigraphic studies. The coastline east and west of the town has been extensively studied, but there have been few publications in recent years. A notable exception is the memoir by Edwards (1999) which applies modern stratigraphical practice to the Penarth Group succession. Early records usually contain little stratigraphical detail (e.g. Bristow, 1864; Woodward, 1893), but two papers are noteworthy for giving logs and more explanation (Dawkins, 1864; Etheridge, 1877). The first major work was by Richardson (1911) who, in a classic paper on the 'Rhaetic' of Somerset, gave minutely detailed logs, including one for the succession at Blue Anchor Point, about a kilometre west of the site of the ostracod sample described herein. The sample was collected from a cliff section in Warren Bay (Fig. 1a [UK national grid reference ST 05798 43311]), which exposes a succession (Fig. 2) from the higher beds of the Cotham Member (Lilstock Formation, Penarth Group) well into the Planorbis Zone of the Lias Group (Fig. 3).
Richardson's (1911) paper remained the main stratigraphical reference point for the successions around Watchet until the revisions of Whittaker (1978), Whittaker \& Green (1983) and Edwards (1999). Following these revisions, and on the basis of recent measurements, it is now known that in the Watchet area, the shaly upper part of the Langport Member varies between $23 \mathrm{~cm}$ and $36 \mathrm{~cm}$ in thickness. At the ostracod sample site, it is $26 \mathrm{~cm}$ thick (Fig. 2b).

The Langport Member contains an upper development of dark shales only in the north Somerset and South Glamorgan areas. Around Watchet the unit, previously known as the 'Watchet Beds' or 'Watchet Member', consists of a thin group of distinctive soft, dark grey, silty shales, sometimes containing nodular developments of limestone, occurring between typical paler micrites and shales of the lower part of the Langport Member and 'paper shales', which mark the base of the Lias Group (Fig. 3). It has been reported that these upper Langport Member shales are poorly fossiliferous and virtually devoid of ostracods and foraminifera (Hallam, 1990); however, at localities such as Lavernock Point and St Mary's Well Bay in South Glamorgan, bivalves and microfauna are abundant, albeit with low species diversity. Around Watchet the lowermost horizons contain abundant ostracods, including the fauna described in this paper, together with rarer foraminifera and much echinoderm debris.

\section{THE OSTRACOD FAUNA}

Ostracods were recovered from the sample by the use of the petroleum ether disaggregation process (Swift, 1987). An exceptionally abundant ostracod fauna resulted from the breakdown of the sample. Much of it (and other fossil material) is fragmented, suggesting that deposition took place in a high energy, winnowing setting, perhaps as a transgressive lag or in the intertidal zone. Because of the exceptionally high abundance in the disaggregated residue, complete removal of all ostracod material was not practicable, so a representative $1 \mathrm{~g}$ split fraction was picked clean of all identifiable specimens to give an indication of the relative abundance of species. The identifiable fauna (carapaces, complete valves and large fragments) from the representative split consisted of just five species; Ogmoconchella bristolensis (3108 specimens, 55.5\%), Cytherella plattensis (1624 


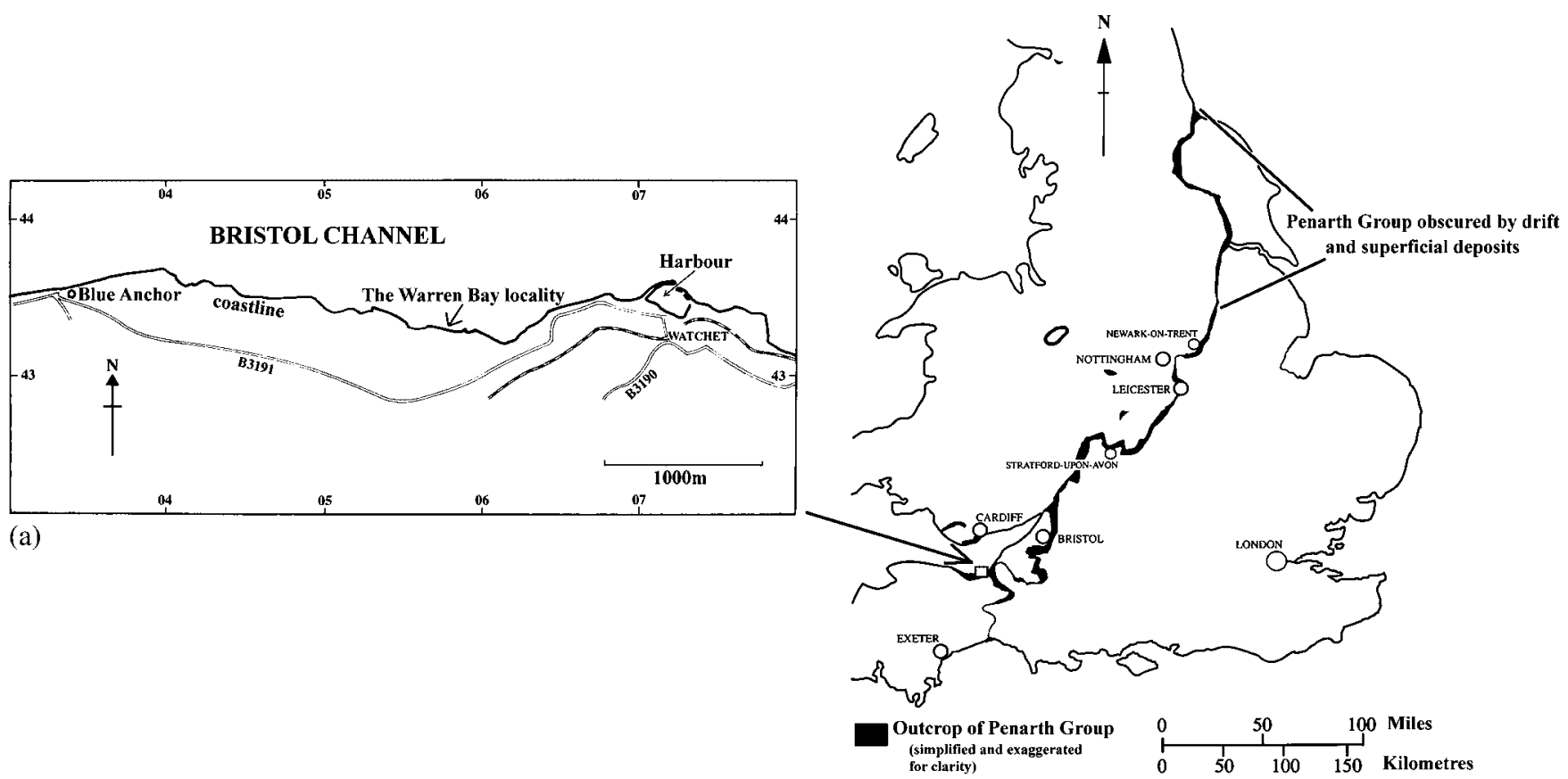

(b)

Fig. 1. (a) The coastline between Watchet and Blue Anchor showing the Warren Bay sample site (simplified from Hamilton \& Whittaker, 1977). (b) The Penarth Group outcrop in England and the location of the Watchet area (after Swift, 1995).

specimens, 29\%), Cytherelloidea praepulchella n. nom. (308 specimens, 5.5\%), Eucytherura sagitta n. sp. (302 specimens, $5.4 \%$ ) and E. minor n. sp. (258 specimens, 4.6\%). O. bristolensis and $C$. plattensis constitute the overwhelmingly dominant elements in the fauna and, together, form $84.5 \%$ of the total of identifiable ostracods recovered.

The low diversity of the ostracod fauna is consistent with the generally low diversity of much of the Penarth Group fauna, and of ostracods in particular. It implies a somewhat abnormal marine setting for the deposition of the shaly upper part of the Langport Member, which inhibited the establishment of a high diversity biota. What the factors were which combined to create this setting are uncertain, but abnormal salinities may have been a factor (Hallam \& El Shaarawy, 1982). However, the presence of abundant echinoderm remains indicates that extreme salinity variations or overly turbid water were not factors, and the abundance of ostracods suggests that food supply was not a problem either. The dark shales of the upper Langport Member were laid down after a hiatus and erosive phase, as demonstrated by the irregular, iron-stained top of the underlying micrite bed, and it is possible that ostracod and other fossil abundances were enhanced by winnowing or reworking. On the other hand, the opening of a new marine niche often results in an initial 'flood' of colonization and the large numbers of ostracods in the basal beds of the shales may reflect this.

Following the identification of the new species of $\mathrm{Eu}$ thytherura from the base of the upper Langport shales at Warren Bay, a search was made in other Penarth Group samples, and a few valves of $E$. sagitta and $E$. minor were recovered from a shale in the underlying lighter-coloured micritic facies of the Langport Member at the same locality, and also from the basal beds of the upper Langport Member shales at St Audrie's Bay, Somerset.

\section{SYSTEMATIC DESCRIPTIONS}

All type material and other illustrated specimens are held in the collections of the British Geological Survey at Keyworth, Nottingham.

Order Podocopida Müller, 1894

Suborder Podocopina Sars, 1866

Superfamily Cytheroidea Baird, 1850

Family Cytheruridae Müller, 1894

Genus Eucytherura Müller, 1894

Type species. Cythere complexa Brady, 1867 (by subsequent designation: Alexander, 1936).

Diagnosis. See Ayress et al. (1995).

Remarks. Until the work of Whatley \& Boomer (2000), the systematics of the ostracod family Cytheruridae were in a confused state, and spurious genera and questionable assignments were common. However, following that work, it is now clear that only a few genera are valid within the family. Small, sub-rectilinear, ornate forms such as the two new species described here are best accommodated in Eucytherura, despite the lack of a spinose caudal process.

\section{Eucytherura sagitta $\mathrm{n} . \mathrm{sp}$.}

(P1. 1, figs 1-15)

Derivation of name. A reference to the arrow-like shape of the carapace when viewed dorsally and ventrally.

Diagnosis. A small species of Eucytherura that is characterized by prominent medial and ventral ridges, and sub-rectangular 

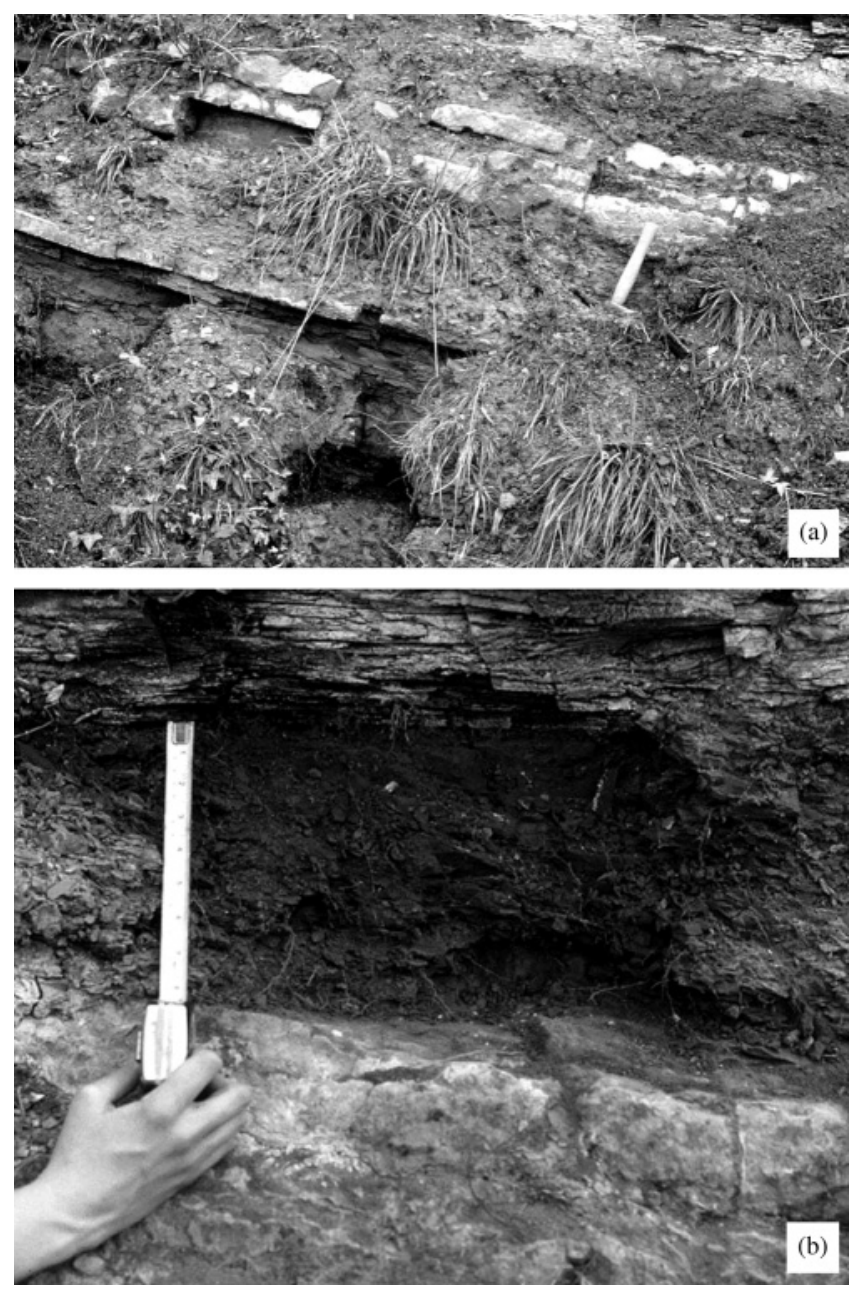

Fig. 2. Photographs of the sample site at Warren Bay: (a) overall view of the section, from the upper levels of the Cotham Member (bottom left) to the 'paper shales' of the Lias Group (top right); hammer shaft is $20 \mathrm{~cm}$ long; (b) close-up of the $26 \mathrm{~cm}$ thick upper shale unit, underlain by micrites of the Langport Member and overlain by fissile 'paper shales' at the base of the Lias Group.

outline in lateral view. Posterior margin and antero-dorsal corner developed as areas of lower relief relative to the general level of the valves, inner edges of both areas marked by ridges.

Holotype. Carapace, MPK 13034.

Material. Several hundred disarticulated valves, several carapaces.

Locality and horizon. Warren Bay, near Watchet, Somerset (UK national grid reference [ST 05798 43311], GPS reading). Upper Langport Member, Lilstock Formation, Penarth Group; Rhaetian, Late Triassic in age.

Description. Carapace small, elongate, tapering gradually posteriorly. Sub-rectangular in lateral view (Pl. 1, figs 1, 6-8, 11-13), arrow-shaped in dorsal and ventral views (Pl. 1, figs 2-5). Highest point near anterior end. Dorsal margin straight, dorsal area has series of poorly developed transverse ridges (Pl. 1, figs

\begin{tabular}{|c|c|c|c|c|}
\hline \multicolumn{2}{|c|}{ Chronostratigraphic Units } & \multicolumn{3}{|c|}{ Lithostratigraphic Units } \\
\hline Jurassic & Hettangian & \multirow[t]{2}{*}{$\begin{array}{l}\text { Lias } \\
\text { Group }\end{array}$} & & \\
\hline \multirow{7}{*}{$\begin{array}{l}-\infty \\
0 \\
0\end{array}$} & \multirow{4}{*}{$\frac{\sqrt[\sigma]{\sigma}}{\sqrt[\sigma]{\sigma}}$} & & & Pre-planorbis Beds \\
\hline & & \multirow{3}{*}{ 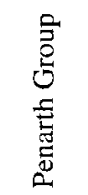 } & \multirow{2}{*}{$\frac{4}{8}$} & Langport Member \\
\hline & & & & Cotham Member \\
\hline & & & \multicolumn{2}{|c|}{ Westbury Formation } \\
\hline & \multirow{3}{*}{ 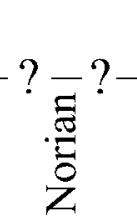 } & \multirow{3}{*}{ 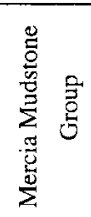 } & \multirow{2}{*}{ 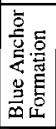 } & Williton Member \\
\hline & & & & $\underset{\text { (west Someresset tenly) }}{\text { Rydon }}$ \\
\hline & & & & \\
\hline
\end{tabular}

Fig. 3. Stratigraphy of the British Late Triassic (after Warrington et al., 1980; Swift, 1995).

2, 3). Ventral area flattened, with fine anastomosing ridges (Pl. 1, figs 4, 5). Lateral surfaces possess medial and ventral ridges. Medial ridge stops short of anterior and posterior ends, ventral ridge bends towards the anterior margin but terminates before reaching it. Posterior and antero-dorsal regions flattened and set at lower level relative to rest of valves, these features are slightly more pronounced in the left valve. The inner edges of both areas of lower relief are marked by ribs. Ornament consists of poorly defined pits or coarse reticulae. The eye tubercle consists of antero-dorsal swelling on or just below the anterior longitudinal rib. Internal features obscure, hingement apparently simple (Pl. 1, fig. 15).

Dimensions. Holotype length $355 \mu \mathrm{m}$, maximum height $140 \mu \mathrm{m}$. Average length of the paratypes $360 \mu \mathrm{m}$, and height $141 \mu \mathrm{m}$.

Remarks. This taxon and Eucytherura minor are the first new species of ostracods to be described from Rhaetian strata in Britain since the work of Anderson (1964). Assignment of these new species to Eucytherura is believed to be appropriate, despite the lack of a caudal spine. These small ostracods do not closely resemble any others previously reported from the Rhaetian, but have greatest similarity to forms described from the Lower Jurassic, particularly ones now referable to the genus $\mathbf{E u}$ cytherura (I. Boomer, pers comm.; Whatley \& Boomer, 2000). The only possibly related form from the Penarth Group is the single left valve of Eocythereis vertebrale Anderson (1964, p. 145, pl. 13, figs 79-80) recovered from the Cotham Member in a railway cutting in Warwickshire, from a level lower than the horizon which yielded E. sagitta. Eocythereis vertebrale is also now assigned to Eucytherura by Whatley \& Boomer (2000), but possesses, amongst other differences, an 'abruptly terminated posterior', 'deep anterior flange' and 'plicate posterior lappets' (Anderson, 1964, p. 145). The species Rutlandella transversiplicata Bate \& Coleman (1975) from the Lower Toarcian of the east Midlands is broadly similar, and forms described as Pleurocythere sp. A by Boomer (1991) from the Toarcian of the Mochras borehole also show some affinity. Both these taxa 


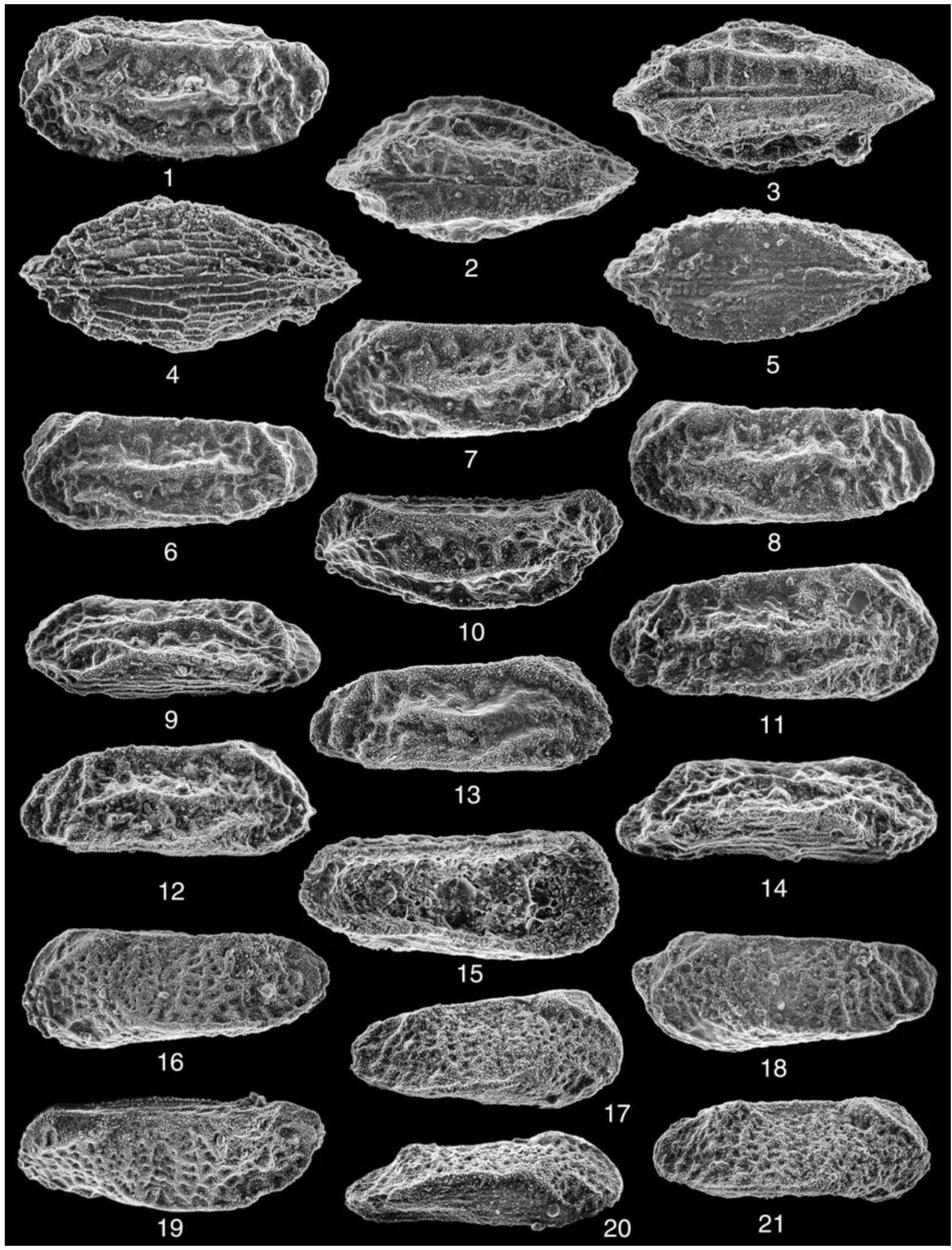


would now be accommodated in Eucytherura (I. Boomer, pers comm.). There is no obvious dimorphism in E. sagitta, but a slight increase in height relative to length is apparent in certain forms and may point to some differentiation.

\section{Eucytherura minor n. sp.}

(Pl. 1, figs 16-21)

Derivation of name. From the small size and delicacy.

Diagnosis. A small species of Eucytherura that is characterized by having the ventral area flattened and developed into a high ventral ridge extending along three-quarters of ventral margin. Dorsal area much narrower. Short, high rib developed at antero-dorsal corner. High, elongate node in postero-dorsal region.

Holotype. Left valve, MPK 13045.

Material. Fairly common in the Warren Bay fauna, but slightly rarer than E. sagitta.

Locality and horizon. Warren Bay, near Watchet, Somerset (UK national grid reference [ST 05798 43311], GPS reading). upper Langport Member, Lilstock Formation, Penarth Group; Rhaetian, Late Triassic in age.

Description. Small, elongate, sub-rectangular in shape, tapering gently to posterior (Pl. 1, figs 16-18). Surface topography irregular, varying from a high ventral ridge to an almost flat dorsal margin, with two prominent raised areas. One is a short ridge located in the antero-dorsal corner above a flattened area of lower relief, the other an elongate node towards the posterodorsal margin, again above an area of lower relief at the posterior end (Pl. 1, figs 19-21). Surface ornament of reticulae. Eye tubercle indistinct, located in antero-dorsal region, on or near the anterior longitudinal rib. Internal features unknown.

Dimensions. Holotype length $351 \mu \mathrm{m}$, maximum height $140 \mu \mathrm{m}$. Average length of the paratypes $323 \mu \mathrm{m}$, and height $133 \mu \mathrm{m}$.

Remarks. E. minor clearly bears a close affinity with E. sagitta, but differs mainly in the less ornate, less ridged lateral surfaces. Also, the species is smaller, less robust and the change in topography across the lateral surface from anterior to posterior and dorsal to ventral is more extreme. The two areas of higher relief are analogous to the two ridges which mark the inner edges of the areas of low relief in E. sagitta, but are more weakly developed. Areas of lower relief at the posterior margin and in the antero-dorsal corner are also comparable with those of E. sagitta.

Suborder Platycopina Sars, 1866

Superfamily Kloedenelloidea Ulrich and Bassler, 1908

Family Cytherellidae Sars, 1866

Genus Cytherelloidea Alexander, 1929

Cytherelloidea praepulchella $\mathrm{n}$. nom.

(Pl. 2, figs 1-14)

1964 Cytherelloidea cf. pulchella Apostolescu; Anderson: 151, pl.

13, figs 74-78.

1978 Cytherelloidea pulchella Apostolescu; Bate: 182, pl. 2, fig. 12.

1999 Cytherelloidea cf. pulchella Apostolescu; Boomer et al:: 133, pl. 19, fig. 4.

Derivation of name. Referring to the earlier occurrence (prae-) of this species than $C$. pulchella, and affirming the phylogenetic relationship with that species (-pulchella).

Diagnosis. A medium-sized species of Cytherelloidea characterized by prominent reticulate patterning, a peripheral rib most strongly developed around anterior margin, two variably developed ridges dorsally and dorso-medially, and a weak ridge ventrally.

Holotype. GSM Mik (J) 289001, held in the collections of the British Geological Survey, Keyworth, Nottinghamshire.

Material. Common in the higher beds of the Penarth Group. Quite common as disarticulated valves in the Warren Bay fauna, carapaces rarer.

Locality and horizon. The holotype is from the upper Langport Member shales at Lavernock Point, near Penarth, South Wales, approximately $2.13 \mathrm{~m}$ below the contact with the 'paper shales' of the Lias Group (Anderson, 1964).

Description. In lateral view the shape is variable, oval to elongate oval. Relatively flat in dorsal and ventral views (Pl. 2, fig. 3), some specimens more inflated (Pl. 2, figs 10, 11, 13, 14). Right valve slightly larger (Pl. 2, fig. 3). Most specimens highest near anterior margin, some specimens more obviously broader at the anterior, tapering gradually to the posterior (Pl. 2, figs 5, 10, 11); others more parallel sided (Pl. 2, figs 1-3). Ventral margin indented at mid-point. A peripheral ridge extends around the whole valve, most strongly developed near anterior and posterior edges, lower close to ventral and dorsal margins (P1. 2, figs

Explanation of Plate 1.

figs 1-15. Eucytherura sagitta n. sp.: 1, 2, holotype, carapace, MPK 13034 - 1, left lateral view; 2, dorsal view; 3, paratype, MPK 13035, carapace, dorsal view; 4, paratype, MPK 13036, carapace, ventral view; 5, paratype, MPK 13037, carapace, ventral view; 6, 9, paratype, MPK 13038, left valve -6, lateral view, 9, ventro-lateral view; 7, 10, paratype, MPK 13039, left valve -7, lateral view, 10, dorso-lateral view; 11, paratype, MPK 13040, right valve, lateral view; 12, paratype, MPK 13041, right valve, lateral view; 13, paratype, MPK 13042, right valve, lateral view; 14, paratype, MPK 13043, right valve, ventro-lateral view; 15, paratype, MPK 13044, left valve, internal view. figs 16-21. Eucytherura minor n. sp.: 16, 19, holotype, left valve, MPK 13045 -16, lateral view, 19, dorso-lateral view; 17, 20, paratype, right valve, MPK 13046 - 17, lateral view, 20, ventro-lateral view; 18, paratype, MPK 13047, left valve, lateral view; 21, paratype, MPK 13048, right valve, lateral view. All specimens from the base of the upper Langport Member, Lilstock Formation, Penarth Group (Rhaetian, Late Triassic), near Watchet, Somerset. All $\times 150$. Repository of specimens: collections of the British Geological Survey, Keyworth, Nottingham, UK. 


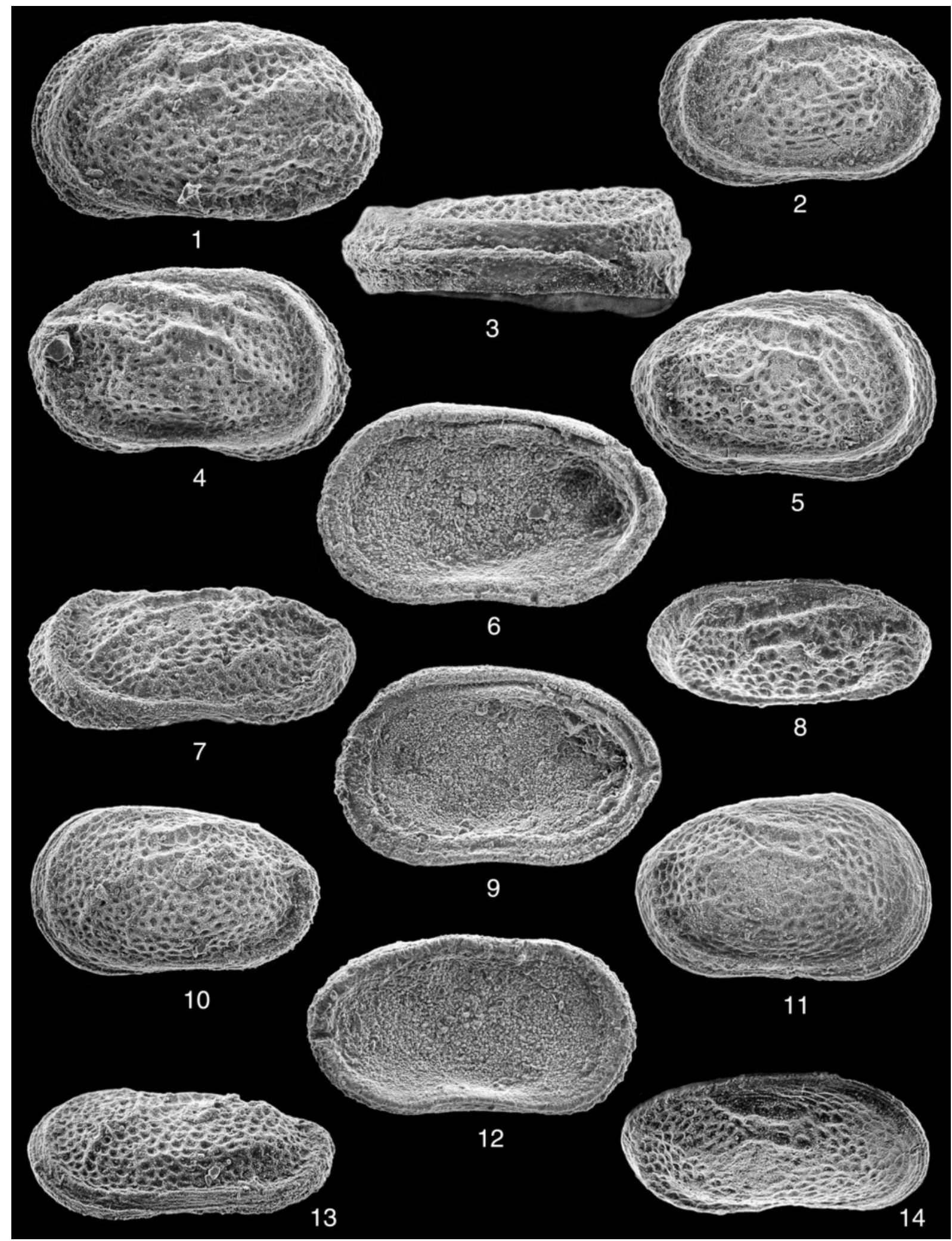


$7,8,13,14)$. Three other ridges present, variably developed. Longest occurs medially, from a point close to or more ventral to the middle of the anterior peripheral ridge (but not joining it), extending sinuously to a point just below the postero-dorsal angle (Pl. 2, figs 1, 2, 4, 5, 7, 8). In some cases this ridge bends ventrally from its path towards the postero-dorsal angle and ends medially (Pl. 2, fig. 5). Another more dorsally positioned ridge originates from a similar point and extends roughly parallel to the medial ridge to a point on the dorsal edge near to the postero-dorsal angle, its line being less sinuous. A fainter ridge near to the ventral margin runs roughly parallel to the other two. In a significant number of cases the ridging is weakly developed, in these cases the valves tend to be more inflated and spade-shaped (Pl. 2, figs 10, 11). Hinge simple, of ridge (left valve) and groove (right valve) type, extending around much of the valve (Pl. 2, figs 6, 9, 12). Dimorphism evident in the two posterior depressions internally in the heteromorph (Pl. 2, fig. 6), which are reflected by rather indistinct bulges on the external morphology.

Dimensions. Average length of illustrated specimens $541 \mu \mathrm{m}$, and average height $310 \mu \mathrm{m}$.

Remarks. Until now this species has been described as Cytherelloidea cf. pulchella (Anderson, 1964; Boomer et al., 1999) or as C. pulchella itself (Bate, 1978), which acknowledges its close relationship to the species erected by Apostolescu in 1959. However, it has generally been considered to be a distinct form (Anderson, 1964; Boomer et al., 1999) and is here formally renamed to indicate its occurrence before the appearance of C. pulchella. It is separated from C. pulchella because the illustrated type material of $C$. pulchella from the Sinemurian of the Paris Basin clearly shows specimens which are robust, sub-rectangular in shape, with prominent ridges and concomitant deep troughs on the lateral surface of the valves (Apostolescu, 1959, pl. 1, figs 4-6). C. praepulchella has less prominent ridges and troughs, possesses a more reticulate surface ornament, is slightly more inflated, and tends to show more distinct tapering from anterior to posterior.

There are records of $C$. pulchella from British Lias Group sediments, and it is interesting to compare the morphology of the specimens described by Field (1966) from south Dorset, which occur at a horizon between the Penarth Group occurrences and Apostolescu's (1959) type material. These specimens occur in the lower part of the Schlotheimia angulata Zone of the Hettangian and show morphology intermediate between that of the older and younger forms. The Hettangian forms have moderately developed ridges and troughs and a relatively flat surface topography, but are more robustly ornamented than the Late Triassic Penarth Group examples; but again, are not so robust as the French Sinemurian forms. There appears to be a line of increasing ridge development and robustness from the Late Triassic to the Sinemurian. In addition, at the anterior end, both the Sinemurian and Hettangian forms have a greater area anterior of the main peripheral ridge than the Late Triassic species.

Cytherelloidea praepulchella shows some variability, both in shape and ornament. Some specimens are sub-rectilinear in lateral view, others tend to be more tapered and approximate to elongate oval in shape. The sub-rectilinear forms also tend to have more pronounced ridges and have flatter surface topography (e.g. compare the sub-rectilinear form of Plate 2, fig. 4 with the elongate ovoid-shaped Plate 2, fig. 11). The rather poor preservation of internal detail does not allow an accurate correlation of this shape variability with the known sexual differentiation, as demonstrated by the two internal pits.

Only one specimen of $C$. praepulchella has been previously figured from the Penarth Group and this specimen (GSM Mik (J) 289001) appears in all three papers which figure Penarth Group ostracods (Anderson, 1964; Bate, 1978; Boomer et al., 1999). Thus, the specimens figured here represent the first illustrations of new material.

\section{Genus Cytherella Jones, 1894 \\ Cytherella plattensis Anderson, 1964}

$$
\text { (Pl. 3, figs 1-4) }
$$

Remarks. This form is a common constituent in upper Penarth Group ostracod faunas, and the Watchet material shows no unusual features. No systematic description is given here, as the species was well described by Anderson (1964), when first erected. Anderson (1964) only figured the holotype and a small juvenile; the holotype was subsequently re-figured by Boomer et al. (1999). The figured specimens herein are therefore the first new material to be illustrated since the species was founded.

$$
\begin{gathered}
\text { Suborder Metacopina Sylvester-Bradley, } 1961 \\
\text { Superfamily Healdioidea Harlton, } 1933 \\
\text { Family Healdiidae Harlton, 1933 } \\
\text { Genus Ogmoconchella Gründel, } 1964 \\
\text { Ogmoconchella bristolensis (Anderson, 1964) }
\end{gathered}
$$

(Pl. 3, figs 5-12)

Remarks. Ogmoconchella bristolensis is the most common ostracod in the Watchet fauna, accounting for $55.5 \%$ of the number of identified specimens. As it is well known and previously adequately described and illustrated by Anderson (1964), Bate (1978) and Boomer et al. (1999), no formal systematic analysis is given here. However, as all published illustrations are of the holotype, the figures in this paper are the first of new specimens. The Watchet material shows some differences in shell

Explanation of Plate 2.

figs 1-14. Cytherelloidea praepulchella n. nom.: 1, MPK 13049, left valve, lateral view; 2, MPK 13050, left valve, lateral view; 3, MPK 13051, carapace, ventral view; 4, MPK 13052, right valve, lateral view; 5, MPK 13053, right valve, lateral view; 6, MPK 13054, right valve, internal view; 7, MPK 13055, left valve, ventro-lateral view; 8, MPK 13056, left valve, dorso-lateral view; 9, MPK 13057, right valve, internal view; 10, 13, MPK 13058, left valve, lateral and ventro-lateral views; 11, 14, MPK 13059, right valve, lateral and dorso-lateral views; 12, MPK 13060, left valve, internal view. All specimens from the base of the upper Langport Member, Lilstock Formation, Penarth Group (Rhaetian, Late Triassic), near Watchet, Somerset. All $\times 100$. Repository of specimens: collections of the British Geological Survey, Keyworth, Nottingham, UK. 





morphology and two morphotypes are apparent. In lateral view, one is compressed and broad, the other more elongate and narrow. This is shown in both valves (P1. 3, figs 6, 7, 9, 10), and appears to be independent of the size difference between the larger left valve and the smaller right valve. However, because the difference in most cases is quite small, it is uncertain whether it is a real biological and, presumably, sexual differentiation, or merely indicative of variations in a very large population.

\section{ACKNOWLEDGEMENTS}

I am indebted to Ian Boomer (Department of Geography, University of Newcastle) for critically reading the manuscript and assistance with the taxonomic affinities of the fauna. I am also grateful to two referees for their comments which led to improvements in the manuscript.

\section{Manuscript received 18 February 2002 Manuscript accepted 5 August 2003}

\section{REFERENCES}

Alexander, C.I. 1929. Ostracoda of the Cretaceous of north Texas. University of Texas Bulletin, 2907: 1-137.

Alexander, C.I. 1936. Ostracoda of the genera Eucytherura, Cytherura and Loxoconcha from the Cretaceous of Texas. Journal of Paleontology, 10: 689-694.

Anderson, F.W. 1964. Rhaetic Ostracoda. Bulletin of the Geological Survey of Great Britain, 21: 133-174.

Apostolescu, V. 1959. Ostracodes du Lias du Bassin de Paris. Révue de l'Institut Français du Petrole et Annales des Combustibles Liquides, 14: 795-826.

Ayress, M.A., Whatley, R.C., Downing, S.E. \& Millson, K.J. 1995. Cainozoic and Recent deep sea Cytherurid Ostracoda from the south western Pacific and eastern Indian oceans, part 1: Cytherurinae. Records of the Australian Museum, 47: 203-223.

Baird, W. 1850. The natural history of the British Entomostraca. Ray Society, London, viii+346 pp.

Bate, R.H. 1978. The Trias. In: Bate, R.H. \& Robinson, E. (Eds), A stratigraphical index of British Ostracoda. Seel House Press, Liverpool, 175-188.

Bate, R.H. \& Coleman, B.E. 1975. Upper Lias Ostracoda from Rutland and Huntingdonshire. Bulletin of the Geological Survey of Great Britain, 55: 1-42.

Boomer, I.D. 1991. Lower Jurassic ostracod biozonation of the Mochras Borehole. Journal of Micropalaeontology, 9: 205-218.

Boomer, I.D., Duffin, C.J. \& Swift, A. 1999. Arthropods 1 Crustaceans. In: Swift, A. \& Martill, D.M. (Eds), Fossils of the Rhaetian Penarth Group. Palaeontological Association Field Guide to Fossils, 9: 129-148.

Brady, G.S. 1867. Report on the Ostracoda dredged amongst the Hebrides. Report of the British Association for the Advancement of Science, 1866: 208-211.

Bristow, H.W. 1864. On the Rhaetic (or Penarth) Beds of the neighbourhood of Bristol and the south-west of England. Geological Magazine, 1: $236-239$.

Dawkins, W.B. 1864. On the Rhaetic Beds and White Lias of western and central Somerset; and on the discovery of a new fossil mammal in the Grey Marlstones beneath the Bone-bed. Quarterly Journal of the Geological Society, London, 20: 396-412.

Edwards, R.A. 1999. The Minehead district - a concise account of the geology. Memoir for 1:50 000 Geological sheet 278 and part of sheet 294 (England and Wales). Memoir of the British Geological Survey: i-xii+1-128 pp.

Etheridge, R. 1877. Notes upon the physical structure of the Watchett area, and the relation of the Secondary Rocks to the Devonian series of West Somerset. Proceedings of the Cotteswold Naturalists' Field Club, 6: 35-48.

Field, R.A. 1966. Species of the family Cytherellidae (Ostracoda) from the Lower Lias of south Dorset, England. Senckenbergiana Lethaea, 47: 87-105.

Gründel, J. 1964. Zur Gattung Healdia (Ostracoda) und zu einigen verwandten Formen aus dem unteren Jura. Geologie, 13: 456-477.

Hallam, A. 1990. Correlation of the Triassic-Jurassic boundary in England and Austria. Journal of the Geological Society, London, 147: 421-424.

Hallam, A. \& El Shaarawy, Z. 1982. Salinity reduction of the endTriassic sea from the Alpine region into northwestern Europe. Lethaia, 15: 169-178.

Hamilton, D. \& Whittaker, A. 1977. Coastal exposures near Blue Anchor, Watchet and St Audrie's Bay, north Somerset. In: Savage, R.J.G. (Ed.), Geological excursions in the Bristol District. University of Bristol Press, Bristol, 101-109.

Harlton, B.H. 1933. Micropaleontology of the Pennsylvanian Johns Valley Shale of the Quachita Mountains, Oklahoma, and its relationship to the Mississippian Caney Shale. Journal of Paleontology, 7: 3-29.

Müller, G.W. 1894. Die Ostracoden des Golfes von Neapel und der angrenzenden Meeres-abschnitte, Herausgegeben von der Zoologischen Station zu Neapel, 21: i-vii+1-404 pp.

Richardson, L. 1911. The Rhaetic and contiguous deposits of West, Mid, and part of East Somerset. Quarterly Journal of the Geological Society, London, 67: 1-74.

Sars, G.O. 1866. Oversigt af Norges marine Ostracoder. Forhandlinger $i$ Videnskabs-Selskabet i Christiania, 1865: 1-130.

Swift, A. 1987. The petroleum ether method for the disaggregation of clastic sediments. In: Austin, R.L. (Ed.), Conodonts: investigative techniques and applications. Ellis Horwood, Chichester, 44.

Swift, A. 1995. Conodonts from the Late Permian and Late Triassic of Britain. Monograph of the Palaeontographical Society, 149(598): $1-80$.

Sylvester-Bradley, P.C. 1961. In: Benson, R. H., Berdan, J. M., Bold, W. A. van den et al. Systematic descriptions. In: Moore, R.C. (Ed.), Treatise on Invertebrate Paleontology. Part Q, Arthropoda, 3: Crustacea, Ostracoda. Geological Society of America and University of Kansas Press, Boulder, Colorado, and Lawrence, Kansas, Q99-Q422.

Ulrich, E.O. \& Bassler, R. S. 1908. New American Paleozoic Ostracoda. Preliminary revision of the Beyrichiidae, with descriptions of new genera. Proceedings of the United States National Museum, 35: 277-340.

Warrington, G., Audley-Charles, M.G. \& Elliott, R.E. 1980.et al. A correlation of Triassic rocks in the British Isles. Special Report of the Geological Society, London, 13: 1-78.

Whatley, R. \& Boomer, I. 2000. Systematic review and evolution of the early Cytheruridae (Ostracoda). Journal of Micropalaeontology, 19: 139-151.

Whittaker, A. 1978. The lithostratigraphical correlation of the uppermost Rhaetic and lowermost Liassic strata of the west Somerset and Glamorgan areas. Geological Magazine, 115: 63-67.

\section{Explanation of Plate 3.}

figs 1-4. Cytherella plattensis Anderson: 1, MPK 13061, right valve, lateral view; 2, MPK 13062, left valve, lateral view; 3, MPK 13063, right valve, internal view; 4, MPK 13064, left valve, internal view. Figs 5-12. Ogmoconchella bristolensis (Anderson): 5, MPK 13065, carapace, right lateral view; 6, MPK 13066, left valve, lateral view; 7, MPK 13067, left valve, lateral view; 8, MPK 13068, right valve, lateral view, close up of anterior lip; 9, MPK 13069, right valve, lateral view; 10, MPK 13070, right valve, lateral view; 11, MPK 13071, right valve, lateral view showing wrinkled ornament in dorsal area; 12, MPK 13072, left valve, internal view. All specimens from the base of the upper Langport Member, Lilstock Formation, Penarth Group (Rhaetian, Late Triassic), near Watchet, Somerset. All $\times 100$, except fig. $8 \times 250$. Repository of specimens: collections of the British Geological Survey, Keyworth, Nottingham, UK. 
A. Swift

Whittaker, A. \& Green, G.W. 1983. Geology of the country around Weston-super-Mare. Memoir for 1:50 000 geological sheet 279, New Series, with parts of sheets 263 and 295. Memoir of the Geological Survey of Great Britain: $\mathrm{i}-\mathrm{x}+1-147 \mathrm{pp}$.
Woodward, H.B. 1893. The Jurassic rocks of Britain, Vol. 3. The Lias of England and Wales (Yorkshire excepted). Memoirs of the Geological Survey, England and Wales: i-xii+1-399 pp. 